\title{
IAMJ
}

INTERNATIONAL

AYURVEDIC

MEDICAL JOURNAL

Research Article

ISSN: 2320-5091

Impact Factor: 6.719

\section{A CONTROLLED CLINICAL STUDY TO EVALUATE THE EFFECT OF KETAKI NIRUHA BASTI IN MADHUMEHA WITH SPECIAL REFERENCE TO DIABETES MELLITUS-II}

\author{
Akshatha. $\mathbf{M}^{1}$, Ananta S Desai ${ }^{2}$ \\ ${ }^{1} \mathrm{PG}$ scholar, ${ }^{2}$ Guide and HOD, \\ Department of PG Studies in Panchakarma, Government Ayurveda Medical College, Bengaluru-09, Karnataka, \\ India
}

Corresponding Author: akshatham77@gmail.com

\section{https://doi.org/10.46607/iamj1109102021}

(Published Online: October 2021)

Open Access

(C) International Ayurvedic Medical Journal, India 2021

Article Received: 01/10//2021 - Peer Reviewed: 09/10/2021 - Accepted for Publication: 11/10/2021

Check for updates

\section{ABSTRACT}

Introduction: A controlled clinical study to evaluate the effect of Ketaki Niruha Basti in Madhumeha with special reference to Diabetes mellitus-ii with Madhutailika Basti being the controlled group. Methods: It was an openlabel controlled parallel-group study at a government Ayurveda medical college and hospital in South India. 41 subjects fulfilling inclusion criteria were selected through a convenient sampling method. Group A (study group) 21 subjects were included and 1 dropped out and in Group B (control group) 20 subjects were included. Group A was administered with Ketaki Niruha Basti and Group B was administered with Madhutailika Basti in Yoga Basti pattern. Both the groups were given Murchita Taila for Anuvasana. Results: The effect of the therapy was assessed by analyzing subjective and objective parameters before and after the treatment. While comparing the effect between the groups of Ketaki Niruha Basti and Madhutailika Basti, it showed no significant statistical difference. Conclusion: Ketaki Niruha Basti showed marginally better results in polyphagia, polydipsia, FBS and PPBS while Madhutailika Basti showed better results in polyuria day, polyuria night, tiredness and BMI.

Keywords: Basti, Diabetes Melitus-II, Ketaki Niruha Basti, Madhumeha, Madhutailika Basti. 


\section{INTRODUCTION}

Madhumeha is a multifactorial disease involving all the Doshas, Dhatus, Srotas and Ojas. It is one among Astamahagada $^{1 a, \mathrm{~b}, \mathrm{c}}$ and Agra in Anushangi Vyadhi ${ }^{2}$ that shows the dreadfulness of the disease. As Madhumeha is Krichrasadya[Difficult to cure] or Yapya[managable] condition, good control and effective management should be the aim to reduce the risk of the development of further complications.

Diabetes mellitus-2 can be equated with Madhumeha as both have similar etiologies, symptoms and complications.

In 2020, according to the International Diabetes Federation (IDF), 463 million people have diabetes in the world and 88 million people in the Southeast Asia region. Of these 88 million people, 77 million belong to India. ${ }^{3}$ The prevalence of diabetes in the population is $8.9 \%$, according to the IDF. Its incidence is also increasing at an alarming rate. So, it Has become of utmost importance to find ways to combat this disease. Among the Panchakarma Chikitsa, Basti Karma has its unique importance in treating major diseases. It has a reputation on behalf of the entire treatment. ${ }^{4}$ Though Vamana and Virechana are prime Samshodhana modalities for Prameha as told in Samhita, but nonpalatability, Ushna and Kshara properties of drugs may induce discomfort to the patient. ${ }^{5}$ On the other hand Basti is a comfortable treatment compared to the other two. Acharya Charaka in Siddi Sthana quoted that if a drug is used orally for a particular disease, it can be used for Basti Karma in the same disease.

Ketaki is one among the wide variety of drugs that have been described in the treatment of Meha. ${ }^{6}$ It is easily available, cost-effective. Traditionally the roots of Ketaki are believed to have antidiabetic, antidiuretic, cardiotonic and aphrodisiac properties. ${ }^{7}$ Madhutailika basti is one among the few Bastis told by Samhita in the treatment of Meha. ${ }^{8}$ A study has been conducted on the effect of Madhutailika basti in management of Madhumeha by Doddabasayya $\mathrm{S}$ Swamy and it found statistically significant results, hence this study, "A controlled clinical study to evaluate the effect of Ketaki Niruha Basti in Madhumeha with special reference to Diabetes mellitus-2", aims to assess the Madhumehahara Karma of Kethaki Niruha Basti and Madhutailika Basti, and to find better treatment among these.

\section{Aim and Objectives:}

1. To evaluate the effect of Ketaki Niruha Basti in Madhumeha.

2. To evaluate the effect of Madhutailika Basti in Madhumeha.

3. To compare and ascertain the effect of Ketaki Niruha Basti and Madhutailika Basti in Madhumeha.

\section{Materials and Methods:}

Source of data: Subjects suffering from Madhumeha (Diabetes mellitus type-2) were selected randomly from the OPD and IPD of Jayachamarajendra institute of Indian medicine hospital (Teaching hospital of GAMC), Bengaluru-09

Diagnostic Criteria: Among the screened subjects, Madhumeha is diagnosed based on,

- Fasting plasma glucose level at or above 126 $\mathrm{mg} / \mathrm{dL}$ or $7.0 \mathrm{mmol} / \mathrm{L}$.

- Plasma glucose at or above $200 \mathrm{mg} / \mathrm{dL}$ or $11.1 \mathrm{mmol} / \mathrm{L}$ two hours after $75 \mathrm{~g}$ oral glucose load in glucose tolerance test.

- Random glucose at or above $200 \mathrm{mg} / \mathrm{dL}$ or $11.1 \mathrm{mmol} / \mathrm{L}$.

- HbA1c level at or above $6.5 \%$.

$>$ Subjects fulfilling a minimum of two criteria among the above four, along with HbA1c level at or above $6.5 \%$ were diagnosed to have Diabetes mellitus-II

\section{Inclusion Criteria:}

- Subjects between the ages 25 to 75 years of either gender suffering from type 2 Diabetes mellitus were taken for the study.

- Post prandial blood sugar (PPBS) levels between $160-400 \mathrm{mg} / \mathrm{dL}$ will be taken for the study.

- HbA1c level between 6.5\%-13\%.

- Subjects who are fit for basti will be taken for the study.

\section{Exclusion Criteria:}

- Subjects with type 2 diabetes mellitus who are insulin dependent. 
- Subjects who are diagnosed have complications like diabetic foot, diabetic retinopathy and other secondary complications. Other systemic complications like cardiac, hepatic and renal complications.

- Pregnant and lactating woman.
Assessment Criteria: Assessment is made after analyzing subjective parameters and objective parameters before the intervention, after the intervention and after following up.

Subjective Parameters: Self-formulated scoring scale was used to assess the subjective symptoms.

\begin{tabular}{|l|l|l|l|l|l|}
\hline Sl.no. & Assessment criteria & $\mathbf{0}$ & $\mathbf{1}$ & $\mathbf{2}$ & $\mathbf{3}$ \\
\hline 1. & Polyuria-Day & $3-5$ times & 6-8 times & 9-11 times & $>11$ times \\
\hline 2. & Polyurea-Night & $\begin{array}{l}\text { Does not wake } \\
\text { up }\end{array}$ & Wakes up once & Wakes up twice & $\begin{array}{l}\text { Wakes up more } \\
\text { than twice }\end{array}$ \\
\hline 3. & Polyphagia & $\begin{array}{l}\text { Feels hunger at } \\
\text { Annakala }\end{array}$ & $\begin{array}{l}\text { Feels hunger once in } \\
\text { between Annakala }\end{array}$ & $\begin{array}{l}\text { Feels hunger twice } \\
\text { between annakala }\end{array}$ & $\begin{array}{l}\text { Feels } \\
\text { always }\end{array}$ \\
\hline 4. & Polydipsia & Normal thirst & $\begin{array}{l}\text { Mild increase in } \\
\text { thirst(4-6L) }\end{array}$ & $\begin{array}{l}\text { A moderate increase in } \\
\text { thirst (6.01-8L) }\end{array}$ & $\begin{array}{l}\text { Severe thirst } \\
(8.01-10 \mathrm{~L})\end{array}$ \\
\hline 5. & Tiredness & No tiredness & Mild tiredness & Moderate tiredness & Severe tiredness \\
\hline
\end{tabular}

\section{Objective parameters}

FBS

PPBS

BMI

Study design: "Open-label parallel-group controlled clinical study"

An open-label parallel-group controlled clinical study was conducted. The subjects were assigned to two groups.

Group A (Study group): Subjects of this group received Ketaki Niruha Basti with Murchita Tilataila for Anuvasana Basti in Yoga basti pattern.
This group had 21 subjects, and all received Ketaki Niruha Basti. Out of 21 subjects, 20 completed the study and 1 dropped out.

Group B (Controlled group): Subjects of this group received Madhutailika Basti with Murchita Tilataila for Anuvasana Basti in Yoga Basti pattern.

Group B or the control group had 20 subjects, and all received Madhutailika Basti.

\section{Dosage and drug administration:}

Drug:

Table 1: Showing ingredients and their quantity used in basti

\begin{tabular}{|l|l|l|}
\hline Ingredients & Ketaki niruha basti & Madhutailika basti \\
\hline Madhu & $136 \mathrm{ml}$ & $136 \mathrm{ml}$ \\
\hline Saindhava & $6 \mathrm{~g}$ & $6 \mathrm{~g}$ \\
\hline Murchita tila taila & $70 \mathrm{ml}$ & $136 \mathrm{ml}$ \\
\hline Shatapushpa Kalka & $40 \mathrm{gm}$ & $40 \mathrm{~g}$ \\
\hline Ketaki Kwatha & $310 \mathrm{ml}$ & \\
\hline Eranda mula kwatha & & $310 \mathrm{ml}$ \\
\hline Anuvasana basti & $40 \mathrm{ml}$ & $40 \mathrm{ml}$ \\
\hline
\end{tabular}

Table 2: Pattern of the basti:

\begin{tabular}{|l|l|r|r|r|r|r|r|r|r|}
\hline Basti & Time & Day 1 & Day 2 & Day 3 & Day 4 & Day 5 & Day 6 & Day 7 & Day 8 \\
\hline Niruha & 9-10 am & & $\checkmark$ & & $\checkmark$ & & $\checkmark$ & & \\
\hline Anuvasana & $\mathbf{1 - 2 . 0 0 p m}$ & $\checkmark$ & & $\checkmark$ & & $\checkmark$ & & $\checkmark$ & $\checkmark$ \\
\hline
\end{tabular}




\section{Duration of the study:}

The total duration of intervention: 25 days.

Duration of treatment: 1st -8th day: yoga basti pattern

Parihara Kala for next 16days

Follow up: on 25th day

\section{Statistical analysis}

Friedman's test and Repeated measure ANOVA test was used to analyze the significance of the change in subjective and objective parameters respectively.

Mann Whitney U test and Independent T-test was used to comparing the significance of the change between the groups.

\section{Observation}

Among 41 subjects, 21 subjects were included under Group A (Ketaki Niruha Basti). Out of which 20 subjects completed the study and 1 dropped out. 20 subjects were included under Group B (Madhutailika Basti), and all the subjects completed the study.

In the present study, out of 40 subjects, a maximum number of subjects $(n=31)$ were from the age group of 46-75 years and a slight predominance of males $(n=21)$ over females was found. Religion wise distribution showed that more patients were Hindus $(n=39)$. The majority $(n=38)$ of patients were married. 18 subjects from this study belonged to middle-class families. The majority ( $\mathrm{n}=15)$ were of Pitta Kapha Prikriti. 26 subjects had Madhyama Kosta. A considerable number of cases $(n=26)$ had a positive history of familial tendency. Maximum $(n=31)$ subjects were k/c/o diabetes mellitus-II and majority $(n=26)$ had average Hba1c $>8 \%$. 24 subjects had Polyuria-Day, 22 subjects had polyuria night, 16 had polyphagia 16 had polydipsia and 25 subjects had tiredness. Maximum $(\mathrm{n}=24)$ had 3 vegas after niruha basti. The majority $(n=19)$ subjects had a retention period of 5-8 mins after niruha and 22 subjects had a retention period of 69 hours after anuvasana.

Results: The study was registered with 41 subjects of Diabetes mellitus-II in a double group. Out of which 40 subjects completed the study and 1 dropped out. Among 40 subjects, 20 subjects were included under Group A (Ketaki Niruha Basti) and 20 were included under Group B (Madhutailika Basti)

Friedman's test was run on subjective parameters and both the groups have shown significant improvement in all the symptoms.

Mann Whitney $U$ test was run on subjective parameters between the group, and it was found that there was no significant difference in the action of Ketaki Niruha Basti and Madhutailika Basti on subjective parameters. However, Ketaki Niruha Basti showed marginally better results in Polyphagia and Polydipsia and Madhutailika Basti showed slightly better results in Polyuria- Day, Polyuria-Night and tiredness while comparing the mean values. Results are placed in table no.03

Table 3: Showing comparative effect of ketaki niruha basti and Madhutailika basti on subjective parameters

\begin{tabular}{|c|c|c|c|c|c|c|c|}
\hline Parameter & Group & $\mathbf{N}$ & Mean Rank & Sum of Rank & $\mathbf{Z}$ & $\mathbf{P}$ & Remarks \\
\hline \multirow{3}{*}{ Polyuria-day } & A & 20 & 21.90 & 438.00 & \multirow{3}{*}{-.897} & \multirow{3}{*}{.461} & \multirow{3}{*}{ NS } \\
\hline & B & 20 & 19.10 & 382.00 & & & \\
\hline & Total & 40 & & & & & \\
\hline \multirow[t]{3}{*}{ Polyuria-night } & A & 20 & 22.10 & 442.00 & \multirow{3}{*}{-.988} & \multirow{3}{*}{.398} & \multirow{3}{*}{ NS } \\
\hline & B & 20 & 18.90 & 378.00 & & & \\
\hline & Total & 40 & & & & & \\
\hline \multirow[t]{3}{*}{ Polyphagia } & A & 20 & 20.15 & 403.00 & \multirow{3}{*}{-.244} & \multirow{3}{*}{.862} & \multirow{3}{*}{ NS } \\
\hline & B & 20 & 20.85 & 417.00 & & & \\
\hline & Total & 40 & & & & & \\
\hline \multirow[t]{3}{*}{ Polydipsia } & A & 20 & 19.80 & 396.00 & \multirow{3}{*}{-.520} & \multirow{3}{*}{.718} & \multirow{3}{*}{ NS } \\
\hline & B & 20 & 21.20 & 424.00 & & & \\
\hline & Total & 40 & & & & & \\
\hline \multirow[t]{3}{*}{ Tiredness } & A & 20 & 21.80 & 436.00 & \multirow{3}{*}{-.799} & \multirow{3}{*}{.495} & \multirow{3}{*}{ NS } \\
\hline & B & 20 & 19.20 & 384.00 & & & \\
\hline & Total & 40 & & & & & \\
\hline
\end{tabular}


Graph 1 : Comparing meansquares of subjective parameter between the group

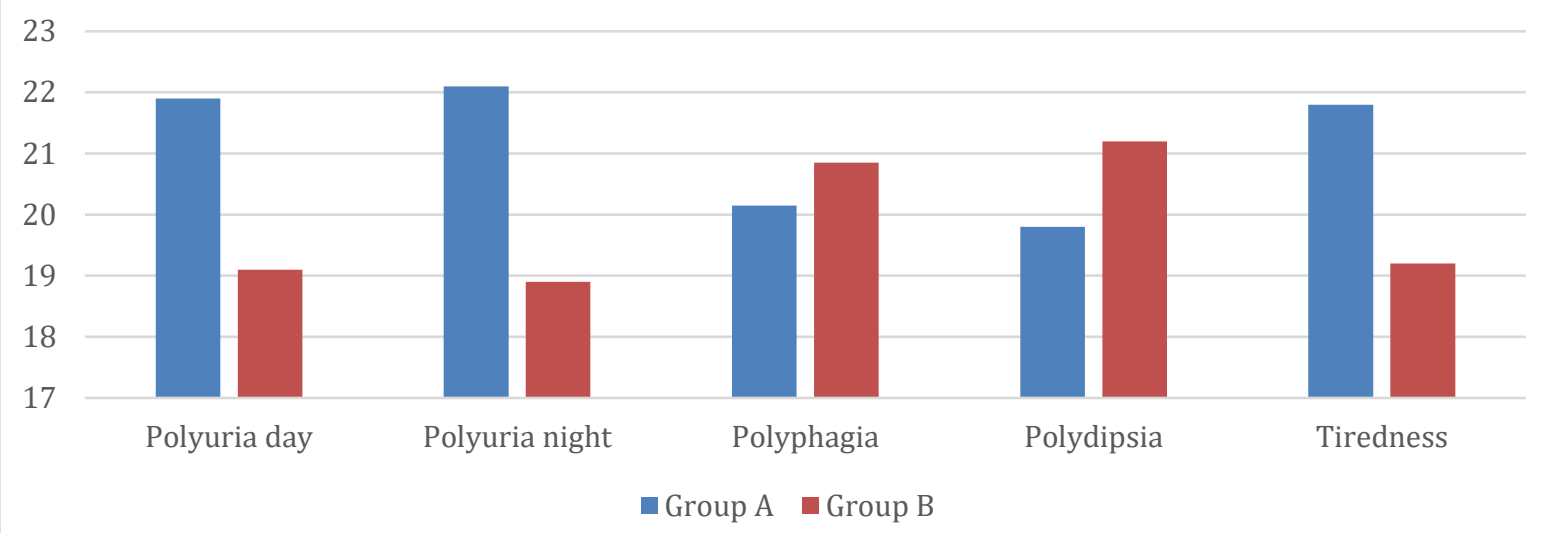

Repeated anova test was run on objective parameters and both the groups have shown significant improvement in all the parameters.

An Independent t-test was run on objective parameters between the group, and it was found that there was no significant difference in the action of Ketaki Niruha
Basti and Madhutailika Basti on objective parameters. However, while comparing the means of objective parameters, FBS and PPBS showed a better reduction in group A or Ketaki Niruha Basti group and BMI showed a better reduction in group B or Madhutailika Basti group.

Table 4: Showing the comparative effect of Ketaki Niruha Basti and Madhutailika Basti on objective parameters by applying an independent t-test.

\begin{tabular}{|l|l|l|l|l|l|l|}
\hline Parameter & Group & N & Mean & Std. Deviation & P-value & Remarks \\
\hline FBS AT & A & 20 & 141.35 & 25.1045 & .993 & NS \\
& B & 20 & 142.30 & 43.87914 & & \\
\hline PPBS AT & A & 20 & 192.10 & 35.92814 & .606 & NS \\
& B & 20 & 201.500 & 72.04933 & & \\
\hline BMI AT & A & 20 & 23.8435 & 3.17098 & .322 & NS \\
\cline { 2 - 5 } & B & 20 & 22.840 & 3.15685 & & \\
\hline
\end{tabular}

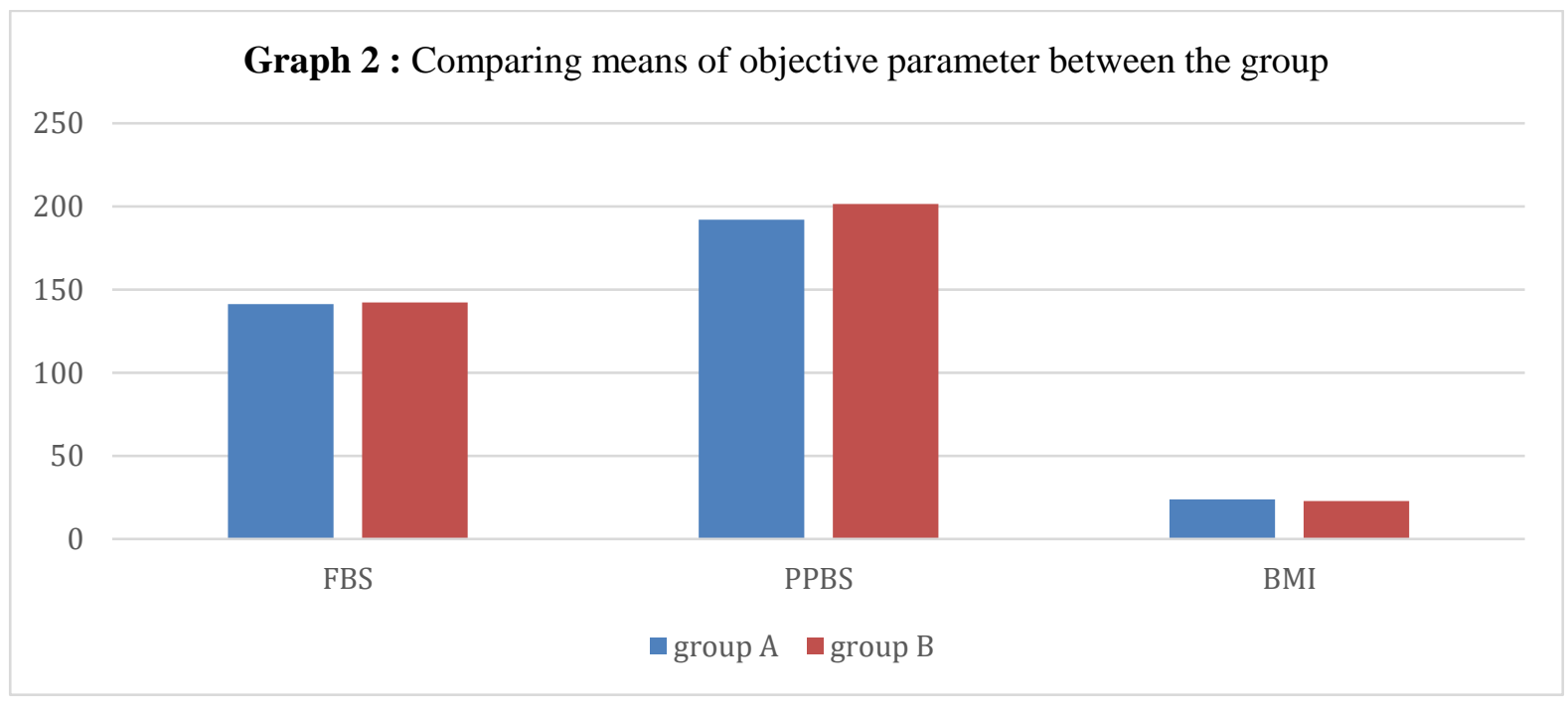




\section{The overall effect of the intervention:}

Among 20 subjects of Ketaki Niruha Basti group or group A, 2(10\%) subjects had no change, 15(75\%) subjects had mild improvement and $3(15 \%)$ subjects are moderately improved.
Among 20 subjects of Madhutailika Basti group or group B, 4(20\%) subjects had no change,13(65\%) subjects had mild improvement and 3(15\%) subjects had moderate improvement.

\section{Graph 3: Overall assessment of Group A}
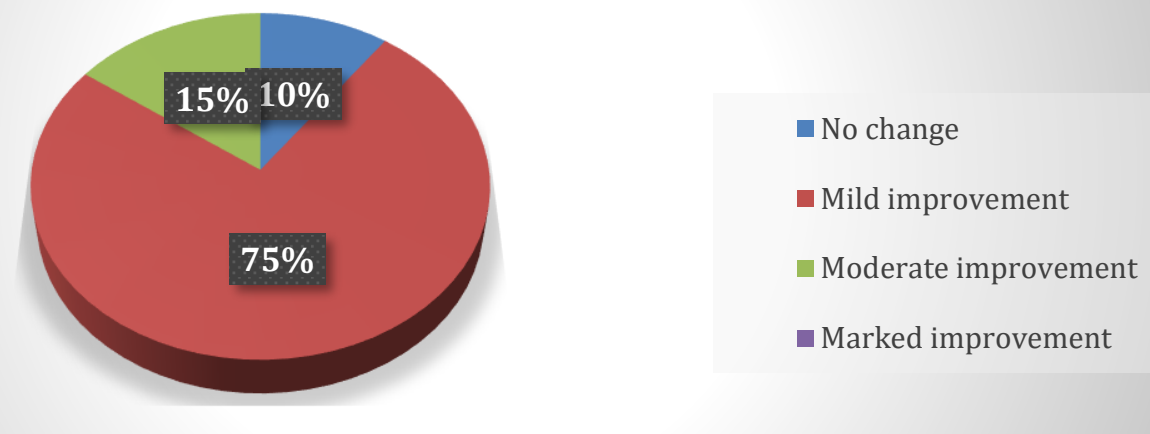

Graph 4: Overall assessment of Group B

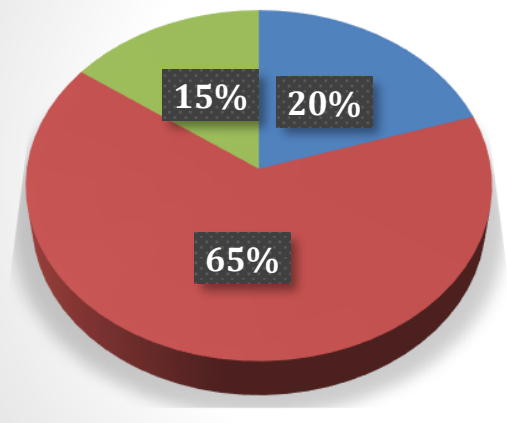

$$
\begin{aligned}
& \text { - No change } \\
& \text { - Mild Improvement } \\
& \text { Moderate improvemeny } \\
& \text { - Marked imrovement }
\end{aligned}
$$

\section{DISCUSSION}

\section{Discussion on basti karma:}

Purvakarma: The person suitable for Basti should be administered with Snehana[oleation] and Swedana[sudation] but Abhyanga[massage] and Sweda are contra-indicated in Santarpanotta Vyadhi. so only Sthanika Abhyanga followed by Mridu Sthanika Swedana in the form of Pata Sweda is administered specifically to Kati, Vankshana, Pakvashaya to achieve proper Vatanulomana and to relax abdominal and local muscles

Pradhana karma: Basti Karma is the best remedy for morbid Vata, but according to Acharya Sushruta it is beneficial even in Kaphaja and Pittaja disorders as it contains various combinations of ingredients. This procedure helps in the management of diseases of all the Roga Margas.

Ketaki niruha basti: Acharya Charaka in Siddistana mentioned that whatever medicine is indicated orally for the Vyadhi[diseases], can be used for Basti in the same Vyadhi. This concept is applied while selecting the Ketaki Niruha Basti.

Madhutailika Basti: it is one among the few Bastis mentioned for the treatment of Prameha. It is a Nirapada Nishparihara Basti, having both Brahmana as well as Lekhana Karma. This Basti is taken as active control group in this study. 
Time of administration of niruha basti dravya: Niruha Basti must be administered on empty stomach according to the classics. In this study, light food is advised to prevent diabetic hypoglycemia.

Basti and madhumeha: according to Indu commentators of Astanga Sangraha, Prameha must be treated with Samshodhana therapy for the purpose of Agni Vriddi and Kledadi Shamana. Acharyas mention Asthapana therapy for Prameha after Vamana and Virechana therapies. At the same time, acharyas included Meha under Basti contraindication. Acharya Chakradatta clarifies that Niruha can be advised in Madhumeha to pacify Vata, which is the main dosha involved in Madhumeha. He also adds that Nisneha Basti mentioned in the quotation can be considered as Alpa Sneha not the absolute contraindication of Sneha. In this regard, Ardhamatrika Basti and Sneha Basti in the dose 40ml which is half of Matra Basti is taken for the study.

\section{Discussion on Drugs:}

Madhu: Madhu has properties like Yogavahitva by which it enhances the properties of the substances with which it is processed. It has Madhura Kashaya Rasa, and it does Karshana by its Rukshadi Guna. It has Kapha Medohara action. It is a natural emulsifying agent.

Saindhava lavana: Saindhava has the property of Deepana, Rochana and Teekshna Guna it is Sukshma Sroto Gami.

Murchita Tilataila: It is best among Taila Varga. It alleviates Vata at the same time it does not aggravate Kapha. Many acharyas mentioned it in the management of Shleshmaja and Medoja Vikara. By its Sukshma Teekshnoshna Gunas, it enters Sukshma Srotas[Minute channels] and does Kshapana of Kapha and Medas.

Shatapushpa Kalka: Due to Ushna Teekshna property it acts as Kapha Vata Shamaka.

Ketaki quatha: Ketaki Quatha is indicated in Madhumeha according to Bharata Bhaishajya Rathnakara. It has Tikta Madhura Katu Rasa, Laghu Snigdha Guna Katu Vipaka Ushna Veerya and Kapha Pitta Shamaka property. The root extract of pandanus odoratissimus showed anti-diabetic activity and free radical scavenging activity in male wistar rats.

Eranda mula quatha: is told Agrya for Vatahara Guna, Ushna Veerya. The roots of ricinis cumunis have free radical scavenging activity by inhibiting lipid peroxidation and helping in fat metabolism.

\section{CONCLUSION}

Following conclusions are drawn based on observations and results which were achieved after systematic and appropriate clinical research.

A number of Vega after Basti administration showed a positive relationship with the type of Kosta. Within the groups, all the subjective and objective parameters showed significant results in both the groups. There was a statistically insignificant result seen between Ketaki Niruha Basti group and Madhutailika Basti group, which proves the null hypothesis. Ketaki Niruha Basti showed a better overall percentage of improvement compared to Madhutailika Basti group.

The overall percentage of improvement in subjective and objective parameters were only marginal. Ketaki Niruha Basti showed better results in polyphagia, polydipsia, FBS and PPBS while Madhutailika Basti showed better results in polyuria day, polyuria night, tiredness and BMI

Ketaki Niruha Basti group showed the better overall percentage of improvement in Pitta Kaphaja Prakriti people as Ketaki is Pitta Kapha Shamaka whereas Madhutailika Basti group better overall percentage of improvement in Vata Kaphaja Prakriti people as Eranda Mula Quatha of Madhutailika Basti is VataKapha hara.

Most subjects had an average retention period within 8-11minutes. The retention period of Niruha Basti showed a directly proportional relationship with the overall effect.

\section{REFERENCES}

1. a. Agnivesha. Charaka Samhita - Revised by Charaka and Dridhabala with Ayurveda Deepika commentary of Chakrapani Datta. Reprint 2015 ed. Indrya sthana 9/8 Chaukhamba Sanskrit Samsthan, Varanasi 2015. b. Sushrutha. Sushrutha Samhita - with Nibandha SangrahaSangraha commentar Sri. Dalhanacharya and Nayayachandrikapanjika of Sri. Gayadasa on 
NidanaSthana, Eight edition 2005 sutra sthana 33/4 i: Chowkamba orientalia; varanasi 2005. c. Vagbhata. AshtangaHridaya- with the commentaries of SarvangaSundara of ArunaDatta and Ayurveda Rasayana of Hemadri, Edited by Bhishagacharya harishastry Paradakara Vaidya, 9th edition. Nidana sthana 8/25 Varanasi: Chaukhamba Orientalia; varanasi 2005 .

2. Agnivesha. Charaka Samhita- Revised by Charaka and Dridhabala with Ayurveda Deepika commentary of Chakrapani Datta. Reprint 2015 ed. Sutra sthana 25/8 Chaukhamba Sanskrit Samsthan, Varanasi 2015.

3. "Members". idf.org. Retrieved 2020-04-29.

4. Agnivesha, Charaka Samhita with Ayurveda Deepika commentary of ChakrapaniDatta edited by Vaidya Jadaviji Trikamji Acharya, Siddhi Sthana 1/39published by Chaukhambha orientalia, Varanasi, Reprint 2015., Pg No-683.

5. Agnivesha, Charaka Samhita with Ayurveda Deepika commentary of ChakrapaniDatta edited by Vaidya Jadaviji Trikamji Acharya,Siddhi Sthana 2/25 published by Chaukhambha orientalia, Varanasi,
Reprint 2015. Pg No-690.

6. Sri Nagin das chaganlal shah, Bharata bhaishajya ratnakara, published by B. Jain publishers, New Delhi. Pg No. 209.

7. Elevitch CR: Traditional trees of Pacific Islands: Their culture, environment and use. Permanent Agriculture Holualoa 2006, Pg No. 565-566.

8. Agnivesha, CharakaSamhita with Ayurveda Deepika commentary of ChakrapaniDatta edited by Vaidya Jadaviji Trikamji Acharya, Siddhi Sthana 12/18/13, Siddhi Sthana 12/18/13, published by Chaukhamba orientalia, Varanasi, Reprint 2015. Pg no. 733.

\section{Source of Support: Nil \\ Conflict of Interest: None Declared}

How to cite this URL: Akshatha. $\mathcal{M}$ Q $\mathcal{L}$ Ananta $S$ Desai: $\mathcal{A}$ Controlled Clinical Study To Evaluate The Effect Of Ketaki Niruha Basti In Madhumeha With Special Reference To Diabetes Melfitus-II. International Ayurvedic Medical Journal \{online\} 2021 \{cited October 2021\} Available from: http://www.iamj.in/posts/images/upload/2360_2370.pdf 